\title{
HUBUNGAN PANJANG TUNGKAI DAN POWER OTOT TUNGKAI DENGAN KEMAMPUAN TENDANGAN PENALTI
}

\author{
Cahyo Pratomo ${ }^{1}$, Aditya Gumantan ${ }^{2}$ \\ Universitas Teknokrat Indonesia ${ }^{1,2}$ \\ cahyo.pratomo987@gmail.com ${ }^{1}$ \\ aditya.gumantan@teknokrat.ac.id ${ }^{2}$
}

Received: 10 Mei 2020

Accepted: 29 Mei 2020

Published : 25 Juni 2020

\begin{abstract}
This reseach study is aimed to investigate leg length and leg power towards penalty kick result of Universitas Teknokrat Indonesia's students majoring in Physical Education batch 2019. Moreover, this study is intended to figure out the impact of leg length and leg power towards penalty kick result. The method used in this study is a descriptive correlational method by having 20 students as a sample of the analysis. The result of this study shows that the correlation between leg length and the accuracy of penalty kick is $56,25 \%$ and the value of correlational coefficient between leg strength and penalty kick result is $67,24 \%$. From these two variables, the biggest contribution of penalty kick result comes from the leg strength with the percentage of $67,24 \%$.
\end{abstract}

Keywords: limbs, power limbs, strength, penalty, football

\begin{abstract}
Abstrak
Penelitian ini bertujuan untuk mengetahui panjang tungkai, power tungkai terhadap hasil tendangan penalti pada mahasiswa Pendidikan Olahraga Universitas Teknokrat Indonesia angkatan 2019. Tujuan dari penelitian ini untuk mengetahui besarnya pengaruh panjang tungkai dan power tungkai terhadap hasil tendangan penalti. Metode penelitian yang digunakan pada penelitian ini yakni deskriptif korelasional dengan sampel berjumlah 20 mahasiswa. Hasil dari penelitian menunjukan bahwa korelasi antara panjang tungkai dengan hasil ketepatan tendangan penalti sebesar 56,25\% kemudian nilai koefesien korelasi antara kekuatan otot tungkai dengan hasil tendangan penalti yakni sebesar $67,24 \%$. Dari ke dua variabel tersebut kontribusi terbesar terhadap hasil tendangan penalti adalah power otot tungkai yaitu sebesar $67,24 \%$.
\end{abstract}

Kata Kunci: Tungkai, Power Tungkai, Kekuatan, Penalti, Sepakbola

\section{To cite this article:}

Pratomo, Cahyo dan Gumantan, Aditya. (2020). Hubungan Panjang Tungkai Dan Power Otot Tungkai Dengan Kemampuan Tendangan Penalti. Journal of Physical Education. 1 (1), 10-17

\section{PENDAHULUAN}

Berdasarkan dari observasi yang dilakukan, bahwa peranan tendangan penalti dalam permainan sepak bola sangat penting. Tendangan penalti merupakan teknik tendangan dengan yang dilakukan langsung ke gawang dalam jarak 11 meter. Dalam tendangan penalti selain penguasaan teknik dasar yang baik antropometri tubuh juga memiliki peranan yang sangat penting. Peneliti melihat dari bentuk antropometri tubuh sampel sangat baik, yakni besar dan tinggi dimana peneliti tertarik untuk mengetahui kekuatan, panjang dan power tungkai sampel yang nantinya dikorelasikan dengan hasil tendangan penalti. Selain penguasaan teknik dasar sepak bola dalam menentukan kesuksesan tendangan penalti, peneliti ingin mengetahui seberapa besarnya peranan otot tungkai dan panjang tungkai terhadap ketercapainya tendangannya penalti.

Berdasarkan observasi tersebut peneliti mengindentifikasi masalah sebagai berikut;kurangnya pengetahuan mahasiswa tentang teknik dasar sepakbola yang baik, peranan dari kekuatan panjang tungkai dan power tungkai sangat mempengaruhi terhadap bentuk tendangan. batasan masalah pada penelitian ini yakni panjang tungkai, power tungkai terhadap tendangan penalti pada mahasiswa pendidikan olahraga Universitas 
Teknokrat Indonesia. Tujuan dari penelitian yakni untuk mengetahui besarnya hubungan panjang tungkai, power tungkai terhadap kemampuan tendangan penalti. Manfaat dari penelitian ini yaitu mengetahui secara baik peranan power tungkai dan kekuatan tungkai terhadap hasil tendangan penalti yang nantinya menjadi rujukan untuk penelitian selanjutnya.

\section{TELAAH PUSTAKA \\ Sepakbola}

Sepakbola merupakan olahraga permainan beregu yang populer didunia. "Gerakan pemain yang baik dan terkontrol mengekpresikan kualitas dirinya dalam permainan sepakbola, kecepatan, stamina, kekuatan, keterampilan dan pengetahuan mengenai taktik merupakan aspek yang penting dalam mendukung permainan" (Luxbacher, 2012). Alam permainan sepakbola setiap pemain diperbolehkan untuk menggunakan seluruh anggota tubuh kecuali lengan. Hanya penjaga gawang yang diperbolehkan memainkan bola dengan kaki dan lengan. Waktu permainan sepakbola dimainkan dalam dua babak ( $2 \times 45$ menit) dengan waktu istirahat (15 menit) di antara dua babak tersebut. Tujuan permainan sepakbola adalah untuk mencetak gol ke gawang merupakan tujuan dari setiap kesebelasan. Penguasaan teknik dasar sangat penting untuk menunjang dalam permainan sepakbola (Augustyn, 2012). Teknik dasar dalam bermain sepakbola antara lain menendang, menghentikan, menggiring, menyundul, merampas, lemparan kedalam, dan menjaga gawang (Gumantan dan Mahfud, 2018).

Pada penalti, teknik dasar yang sangat berperan adalah tendangan (shooting), penguasaan teknik dasar shooting yang baik akan memaksimalkan hasil dari tendangan yang dilakukan. Selain penguasaan teknik dasar, dalam bermain sepakbola terdapat beberapa aspek yang mendukung kesuksesan dalam bermain sepakbola. Keterampilan menendang melibatkan semua anggota gerak bagian kaki. Menendang bola merupakan suatu usaha untuk memindahkan bola dari suatu tempat ke tempat lain dengan menggunakan kaki (Gumantan dan Mahfud ,2018). Menendang bola dapat dilakukan dengan menggunakan kaki bagian dalam. Kaki bagian luar, dan punggung kaki. Lebih lanjut menendang (passing dan shooting) merupakan salah satu usaha memindahkan bola dari satu tempat ketempat lain dengan menggunakan kaki atau bagian kaki, seorang pemain sepak bola yang tidak dapat menguasai teknik menendang bola dengan benar, maka tidak mungkin menjadi pemain sepakbola yang andal dan baik. Tendangan (kicking) dalam permainan sepakbola identik digunakan untuk menembak bola ke gawang (shooting at the goal) (Gumantan dan Mahfud, 2018).

Berdasarkan fungsinya, menendang bola dapat digunakan sebagai cara memberikan (mengoper) bola kepada teman dalam berbagai jarak dan menembak bola ke arah gawang. Untuk mempunyai kemampuan menendang yang baik pemain harus memiliki kemampuan motorik yang baik. Proses motorik adalah gerakan yang langsung melibatkan otot untuk bergerak dan proses persyaratan yang menjadikan seseorang mampu menggerakkan anggota tubuh (tangan, kaki, dan anggota tubuh). Dalam melakukan tendangan pemain harus memiliki rangkaian gerak yang kompleks dan didukung oleh komponen kondisi fisik dan postur tubuh (Mahfud dan Fahrizqi, 2020). Salah satu aspek biologis yang ikut menentukan pencapaian prestasi dalam olahraga yaitu struktur dan postur tubuh(Fahrizqi , 2018). "Selain penguasaan teknik dasar kondisi fisik dan antropometri tubuh sangat menentukan dalam bermain sepakbola" (Mahfud dkk, 2020). Antropometri tubuh yang sesuai dengan karakteristik permainan sepakbola akan menunjang dalam teknik dasar yang telah dikuasai. Dalam tendangan penalti tungkai merupakan anggota tubuh yang memiliki peranan paling penting.

\section{Panjang Tungkai}

Salah satu komponen yang penting dalam prestasi olahraga yaitu ukuran tubuh, struktur tubuh atau kualitas biometrik. Kualitas biometrik adalah mencakup somatotipe dan pengukuran-pengukuran anthropometrik. Prestasi olahraga memerlukan kualitas biometrik tertentu dengan nomor atau cabang olahraga yang dikembangkan. Postur tubuh anthropometrik sering dijadikan bahan pertimbangan dalam menentukan cabang olahraga yang ditekuni oleh atlet tertentu. Anthropometrik merupakan pengukuran lebih jauh mengenai bagian-bagian luar dari tubuh. salah satu aspek biologis yang ikut menentukan pencapaian prestasi dalam olahraga yaitu struktur dan postur tubuh. Struktur dan postur tersebut meliputi: ukuran tinggi dan panjang tubuh, ukuran besar, lebar dan berat tubuh dan Somatotype (bentuk tubuh) (Sajoto, 1995).

Tungkai merupakan bagian tubuh yang penting bagi pemain sepakbola. Ukuran panjang tungkai sebagai salah satu unsur postur tubuh juga ikut menentukan terhadap pencapaian prestasi dalam olahraga. Apalagi dalam permainan sepakbola, dimana olahraga ini sebagian besar gerakannya menggunakan tungkai. Hal ini sesuai dengan pendapat diatas Tungkai yang panjang akan mendukung dalam teknik dasar menendang. Dalam teknik menendang semakin panjang tungkai maka ayunan yang dihasilkan akan semakin jauh akibatnya akan meningkatkan kecepatan tendangan bola (Fakhruzzaman dkk , 2015) 


\section{Power Otot Tungkai}

Power otot tungkai merupakan kemampuan otot atau sekelompok otot tungkai untuk melakukan gerak secara eksplosif. Power otot merupakan kemampuan seseorang untuk melakukan kekuatan maksimum, dengan usahanya yang dikerahkan dalam waktu yang sependek-pendeknya. Power merupakan perpaduan antara kekuatan dan kecepatan, sehingga untuk meningkatkan power maka faktor kekuatan dan kecepatan harus ditingkatkan bersama-sama melalui program yang sistematis. Kekuatan merupakan komponen biomotor yang paling utama, karena dengan kekuatan dapat meningkatkan kondisi fisik secara keseluruhan, kekuatan dapat menentukan kualitas hidup, karena tanpa kekuatan yang memadai, maka kegiatan yang bersifat mendasar menjadi sulit dan tidak mungkin melakukan sesuatu tanpa dengan bantuan kekuatan. Dengan power tungkai yang baik maka tendangan yang dihasilkan akan semakin keras dan cepat.

Menurut Irianto (2002) Power otot tungkai digunakan untuk menekan tanah akan memberikan reaksi sebesar tekanan yang dilakukan. Dengan demikian peranan power otot tungkai terhadap tendangan penalti adalah memberi tekanan dan memberi sumbangan kekuatan dalam melakukan tendangan. Menurut Nugroho dan Gumantan (2020) power otot tungkai adalah kemampuan untuk mempergunakan otot tungkai secara maksimum dalam waktu yang cepat. Selanjutnya yang dimaksud dengan power otot tungkai dalam penelitian ini adalah kemampuan otot atau sekelompok otot tungkai untuk melakukan kerja atau gerakan dengan mengerahkan tenaga maksimal secara eksplosif.

Setiap jenis keterampilan dalam olahraga dilakukan oleh sekelompok otot tertentu. Kekuatan merupakan komponen yang sangat penting untuk meningkatkan kondisi fisik secara keseluruhan karena kekuatan merupakan daya penggerak setiap aktivitas fisik. Disamping itu kekuatan memegang peranan penting melindungi atlet dari kemungkinan cedera. Dalam tendangan penalti kekuatan otot tungkai mempunyai peranan yang sangat penting terhadap keberhasilan tumpuan dan hasil tendangan. Kekuatan adalah kemampuan otot melakukan kontraksi guna membangkitkan terhadap suatu tahanan. kekuatan otot adalah kemampuan tubuh untuk dapat menggerakkan daya maksimal terhadap objek diluar tubuh. Dalam hal ini objek diluar tubuh adalah bola (Lutan , 2002).

Berdasarkan kajian teoritis yang berhubungan dengan permasalahan, maka dapat dirumuskan hipotesis penelitian sebagai berikut :

1. Terdapat hubungan yang signifikan antara panjang tungkai dengan kemampuan tendangan penalti

2. Terdapat hubungan yang signifikan antara power otot tungkai dengan kemampuan tendangan penalti

3. Terdapat hubungan yang signifikan antara panjang tungkai dan power otot tungkai dengan kemampuan tendangan penalti

\section{METODE}

Penelitian ini menggunakan metode korelasional. Menurut Arikunto (2006) penelitian korelasional merupakan penelitian yang bertujuan untuk menemukan ada tidaknya hubungan. Apabila terdapat hubunganseberapa erat hubungan yang dihasilkan. Sampel dan Populasi dari penelitian ini adalah mahasiswa pendidikan olahraga angkatan 2019 yang mengambil matakuliah dasar gerak sepak bola dan sampel pada penelitian ini 30 orang mahasiswa putra yang dengan mengunakan provosif sampling di lihat mahasiswa yang memiliki badan besar dan tinggi untuk mengetahui korelasi antara power tungkai dan panjang tungkai terhadap kemampuan tendangan penalti. Metode dapat dilihat pada gambar Sebagai Berikut :

1. Variabel Bebas $1\left(\mathrm{X}_{1}\right)$ Adalah Panjang Tungkai

2. Variabel Bebas $2\left(\mathrm{X}_{2}\right)$ Adalah Power Otot Tungkai

3. Variabel Terikat (Y) Adalah Kemampuan Tendangan Penalti

Desain penelitian yang digunakan adalah sebagai berikut:

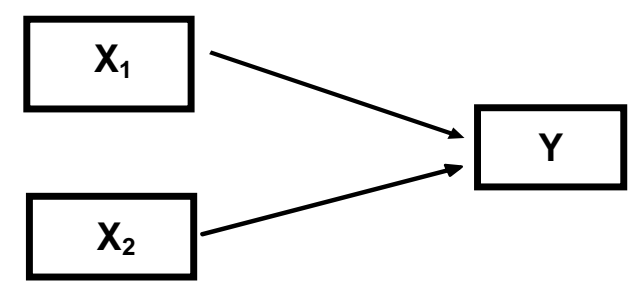

Gambar 1. Desain penelitian variabel $\mathbf{X}$ dan variabel $\mathbf{Y}$ 
Keterangan :

$\mathrm{X}_{1}$ : Panjangtungkai

$\mathrm{X}_{2}$ : Power Otot Tungkai

Y : Kemampuan Gerak Dasar Tendangan Penalti

\section{Teknik Analisis Data}

Tahap Pengolahan data merupakan langkah penting dalam penelitian yang dilakukan. Data yang di nilai adalah data variabel bebas: Panjang Tungkai $\left(\mathrm{X}_{1}\right)$, Power Otot Tungkai $\left(\mathrm{X}_{2}\right)$, serta variable terikat yakni Kemampuan Menendang Bola (Y). Pengujian Hipotesis Analisis dilakukan untuk menguji hipotesis yang telah dilakukan, yaitu untuk mengetahui adakah pengaruh yang diberikan oleh variabel bebas $\left(\mathrm{X}_{1}, \mathrm{X}_{2}\right)$ terhadap variabel terikat $(Y)$ baik secara terpisah maupun secara bersama-sama. Menurut Sugiyono (2010) untuk menguji hipotesis antara $\mathrm{X}_{1}$ dengan $\mathrm{Y}, \mathrm{X}_{2}$ dengan $\mathrm{Y}, \mathrm{X}_{1}$ dan $\mathrm{X}_{2}$ dengan $\mathrm{Y}$ digunakan statistik melalui korelasi product moment dengan rumus sebagai berikut:

$$
\frac{r_{x y}=n \sum X_{i} Y-\left(\sum X_{i}\right)\left(\sum Y_{i}\right)}{\sqrt{\left\{n . \quad X^{2}-\left(\sum X^{2}\right\}\left\{n . \sum i Y^{2}-\left(-\left(\sum Y\right)^{2}\right\}\right.\right.}}
$$

Keterangan :

$\mathrm{r}_{\mathrm{xy}}$

$=$ Koefesien korelasi

$\mathrm{N}=$ Jumlah sampel

$\mathrm{X}=$ Skor variabel

$\mathrm{XY}=$ Skor variabel $\mathrm{Y}$

$\sum \mathrm{X}=$ Jumlah skor variabel $\mathrm{X}$

$\sum \mathrm{Y}=$ Jumlah skor variabel $\mathrm{Y}$

$\sum X^{2}=$ Jumlah kuadrat skor variabel

$\sum \mathrm{Y}^{2}=$ Jumlah kuadrat skor variabel $\mathrm{Y}$

Harga $\mathrm{r}$ yang diperoleh dari perhitungan hasil tes dikonsultasikan dengan Tabel $\mathrm{r}$ product moment. Untuk dapat penafsiran terhadap koefisien korelasi yang ditemukan besar atau kecil, maka dapat berpedoman pada ketentuan yang tertera pada Tabel Interprestasi Koefisien Korelasi Nilai r sebagai berikut:

Tabel 1. Interpretasi Koefisien Korelasi Nilai r.

\begin{tabular}{cl}
\hline \multicolumn{1}{c}{ Interval KoefisienKorelasi } & Interpretasi Hubungan \\
\hline $0,00-0,199$ & Sangat rendah \\
\hline $0,20-0,399$ & Rendah \\
\hline $0,40-0,599$ & Sedang \\
\hline $0,60-0,799$ & Kuat \\
\hline $0,80-1,000$ & Sangat kuat \\
\hline
\end{tabular}

Setelah diketahui besar kecilnya $\mathrm{r}_{\mathrm{xy}}$ maka taraf signifikan dilihat dengan kriteria pengujian hipotesis tolak $\mathrm{H}_{0}$ jika $r_{\text {hitung }}>r_{\text {tabel}}$, dan terima Ho jika $r_{\text {hitung }}<r_{\text {tabel}}$, dan untuk mencari besarnya kontribusi antara variabel $\mathrm{X}$ dan variabel $\mathrm{Y}$ maka menggunakan rumus Koefisien Determinansi : 


$$
\mathrm{KP}=\mathrm{r}^{2} \times 100 \%
$$

Keterangan:

KP : Nilai Koefisien Detreminansi

$r \quad$ : Koefisien Korelasi

\section{HASIL DAN PEMBAHASAN}

Dibawah ini akan dijelaskan hasil dari penelitian yang sudah dilakukan dengan menganalisa hasil pengukuran pada variabel tes penelitian, hasil pengukuran dapat dilihat Sebagai Berikut:

Tabel 2. Deskripsi Data Hasil Tes Panjang Tungkai, Power Otot Tungkai Dan Kemampuan Tendangan Penalti

\begin{tabular}{ccccc}
\hline \multicolumn{6}{c}{ Kemampuan Tendangan Penalti } \\
\cline { 3 - 5 } No & Hasil & \multicolumn{4}{c}{$\begin{array}{c}\text { Panjang } \\
\text { Tungkai }\end{array}$} & $\begin{array}{c}\text { Power Otot } \\
\text { Tungkai }\end{array}$ & $\begin{array}{c}\text { Tendangan } \\
\text { Penalty }\end{array}$ \\
\hline 1 & Sampel & 30 & 30 & 30 \\
\hline 2 & Rata-Rata & 82,4 & 182,6 & 14,92 \\
\hline 3 & SD & 6,27163 & 20,2155 & 4,04063 \\
\hline 4 & Min & 73 & 153 & 22 \\
\hline 5 & Max & 95 & 227 & \\
\hline
\end{tabular}

Deskripsi data digunakan untuk mengetahui gambaran variabel- variabel yang diteliti secara sekilas yaitu meliputi, rata-rata/rerata, standardeviasi, skor minimal dan skor maksimal dari pada mahasiswa. Berikut penjabaran tentang hasil penelitian dari masing-masing variable dapat dilihat pada diagram batang dibawah ini :

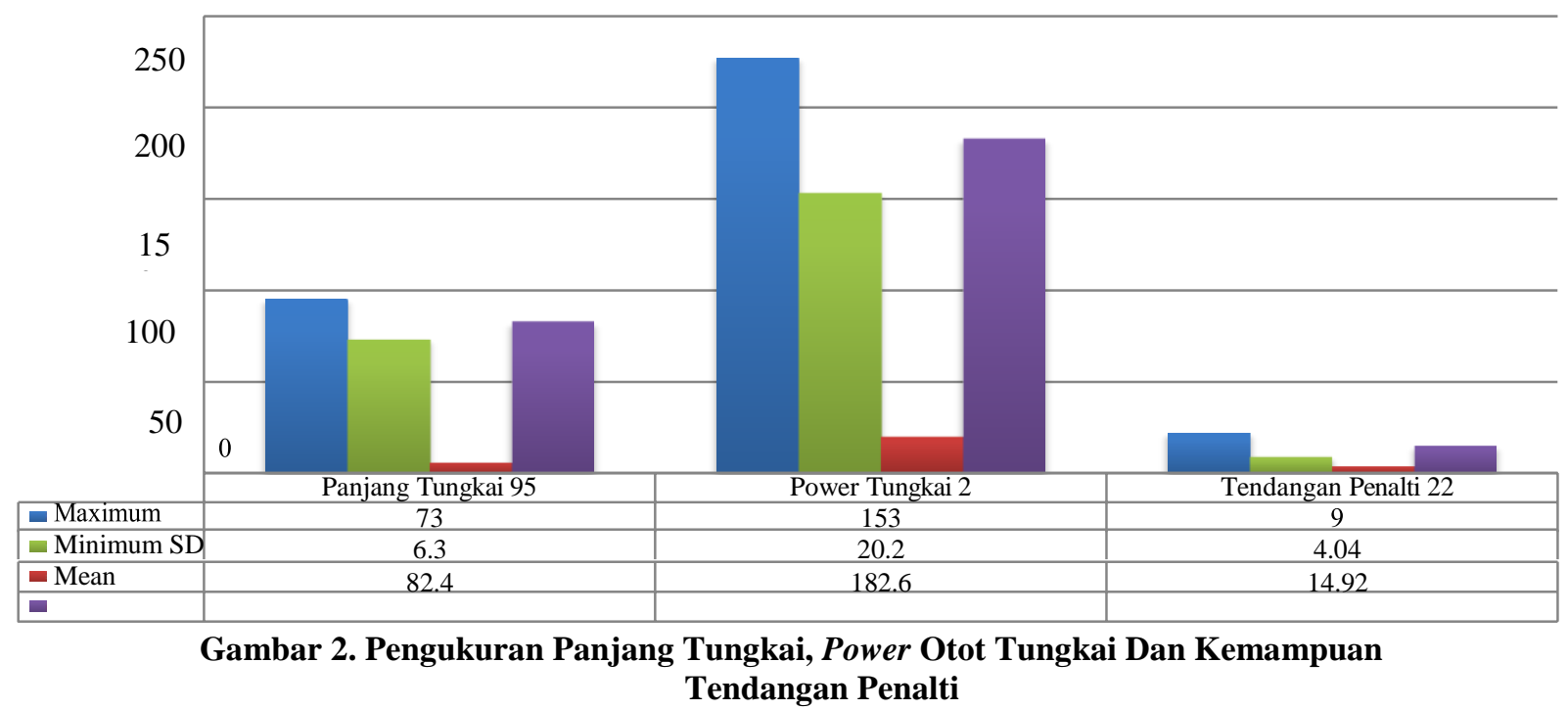

Dari diagram diatas dapat dilihat penjabaran dari nilai maksimum, minimum dan mean dari hasil tingkat pengukuran yang dilakukan pada mahasiswa. Terdapat tiga diagram batang yang masing-masing menginformasikan seberapa besar hasil skor tes pengukuran yang telah dilakukan. 
Tabel 3. Hasil Analisis Hubungan Antara Panjang Tungkai Dengan Kemampuan Tendangan Penalti

\begin{tabular}{lccccc}
\hline \multicolumn{1}{c}{ Variabel } & n & $\begin{array}{c}\text { Koefisiaen } \\
\text { Korelasi }\end{array}$ & $\begin{array}{c}\text { Standar } \\
\text { Deviasi }\end{array}$ & $\begin{array}{c}\text { Kriteria } \\
\text { Korelasi }\end{array}$ & Kesimpulan \\
\hline $\begin{array}{l}\text { Panjang tungkai dengan kemampuan } \\
\text { tendangan penalti }\end{array}$ & 30 & 0,463 & 0,396 & Kuat & Signifikan \\
\hline
\end{tabular}

Dari tabel hasil diatas didapatkan hasil antara variabel panjang tungkai dengan kemampuan penalti dengan koefisien 0,463 dan hasil kesimpulan yang dinyatakan signifikan dengan kriteria korelasi Kuat.

Tabel 4. Hasil Analisis Korelasi Antara Power Tungkai Dengan Kemampuan Tendangan Penalti

\begin{tabular}{lccccc}
\hline \multicolumn{1}{c}{ Variabel } & n $\begin{array}{c}\text { Koefisiaen } \\
\text { Korelasi }\end{array}$ & $\begin{array}{c}\text { Standar } \\
\text { Deviasi }\end{array}$ & $\begin{array}{c}\text { Kriteria } \\
\text { Korelasi }\end{array}$ & Kesimpulan \\
\hline $\begin{array}{l}\text { Power tungkai dengan kemampuan } \\
\text { tendangan penalti }\end{array}$ & 30 & 0,563 & 0,396 & Kuat & Signifikan \\
\hline
\end{tabular}

Dari tabel hasil diatas didapatkan hasil antara variabel power tungkai dengan kemampuan penalti dengan koefisien 0,563 dan hasil kesimpulan yang dinyatakan signifikan dengan kriteria korelasi Kuat

Tabel 5. Hasil Analisis Korelasi Ganda Antara Panjang Tungkai Dan Power Otot Tungkai Dengan Kemampuan Tendangan Penalti

\begin{tabular}{cccccc}
\hline Variabel & $\mathbf{R}$ & $\mathbf{R}^{2}$ & T hitung & T Tabel & Kesimpulan \\
\hline $\begin{array}{l}\text { Panjang tungkai dan power otot tungkai } \\
\text { dengan kemampuan tendangan penalti }\end{array}$ & 0,808 & 0,652 & 20,646 & 3,443 & Signifikan
\end{tabular}

Dari tabel hasil diatas didapatkan hasil antara variabel power tungkai dengan kemampuan penalti dengan T hitung Sebesar 20,646 dan T tabel sebesar 3,443 dan hasil kesimpulan yang dinyatakan signifikan.

\section{Pembahasan}

Dari hasil analisis data yang telah dilakukan didapat koefisien determinasi panjang tungkai sebesar 0,463 yang mengandung arti bahwa panjang tungkai memberikan sumbangan atau kontribusi terhadap kemampuan tendangan penalti sebesar $46,3 \%$, dan sisanya53,7\% ditentukan oleh faktor variabel lain.

Semakin panjang tungkai seseorang semakin panjang dan besar ayunan yang dihasilkan semakin cepat juga kecepatan bola yang dihasilkan sehingga persentase untuk dapat memasukkan bola semakin besar. dengan ayunan yang luas makan kecepatan yang dihasilkan tungkai semakin tinggi.

Dari hasil analisis data yang telah dilakukan didapat koefisien determinasi power tungkai sebesar 0,563 yang mengandung arti bahwa power tungkai memberikan sumbangan atau kontribusi terhadap kemampuan tendangan penalti sebesar 56,3\%, dan sisanya 43,7\% ditentukan oleh faktor/variabel lain. Semakin besar power tungkai maka semakin besar juga kekuatan tendangan bola yang dihasilkan.

Dari hasil analisis data di atas, diperoleh nilai $r$ hitung $(r)=0,808$ dan nilai $\mathrm{R}$ square $\left(\mathrm{r}^{2}\right)$ sebesar 0,652 . $\mathrm{R}$ square dapat disebut koefisien determinasi yang dalam hal ini $65,2 \%$ hubungan yang signifikan variable panjang tungkai dan power tungkai dengan kemampuan tendangan penalti sedangkan $24,8 \%$ ditentukan oleh faktor/variabel lain. Nilai R square berkisar 0 sampai 1, dengan catatan semakin kecil nilai $\mathrm{R}$ square, semakin lemah hubungan ketiga variabel tersebut. Jadi hal ini mengandung makna bahwa apabila siswa memiliki 
hubungan secara bersama-sama variable panjang tungkai dan power tungkai yang normal atau baik maka akan diikuti dengan kemampuan tendangan penalti yang baik pula.

Hal ini dapat dimengerti karena anggota gerak bagian bawah dalam melaksanakan gerakan seperti menendang bola memerlukan ayunan tungkai yang didukung oleh persendian pada panggul. Persendian panggul ini digerakkan oleh otot tungkai dan otot punggung. Sebagai otot penopang tubuh, power tungkai memberikan manfaat yang sangat besar di dalam ayunan tungkai. Ayunan tungkai yang cepat dan kuat dan dengan dibantu panjang tungkai yang baik sehingga akan menghasilkan kecepatan bola yang ditendang semakin tinggi. Semakin panjang tungkai dan kekuatan otot tungkai seseorang maka akan semakin besar juga persentase kekuatan dan kecepatan tendangan penalti yang dilakukan. Saat menendang bola semua kondisi fisik akan berperan aktif, khusus power tungkai.

\section{SIMPULAN}

Berdasarkan hasil penelitian dan analisis data, mengenai hubungan antara panjang tungkai dan power otot tungkai dengan kemampuan tendangan penalti dapat disimpulkan bahwa. Terdapat hubungan yang signifikan antara panjang tungkai dengan kemampuan tendangan penalti. Dibuktikan dengan pengujian hipotesis yang dilakukan. Terdapat hubungan yang signifikan antara power tungkai dengan kemampuan tendangan penalti. Terdapat hubungan yang signifikan antara panjang tungkai dan power otot tungkai dengan kemampuan tendangan penalti.

\section{DAFTAR PUSTAKA}

Arikunto, Suharsimi. (2006). Prosedur penelitian Suatu Pendekatan Praktik. Jakarta: Rineka Cipta. Augustyn, Adam. (2011). The Britannica Guide to Soccer. New York: Britannica Educational Publishing,Inc. Fahrizqi , Eko Bagus. (2018). Hubungan Panjang Tungkai, Power Tungkai Dan Koordinasi Mata-Kaki Dengan Kemampuan Passing Pada Pemain Unit Kegiatan Mahasiswa Olahraga Futsal Perguruan Tinggi Teknokrat. Journal of S.P.O.R.T.2 (1), 32-42.

Fakhruzzaman, Dian. Zulfikar. Abdurrahman. (2015). Hubungan Antara Panjang Tungkai dan Daya Ledak Otot Tungkai Terhadap Kemampuan Menendang Pada Pemain SSB Aneuk Rencong Banda Aceh Tahun 2010. Jurnal ilmiah mahasiswa pendidikan jasmani, kesehatan dan rekreasi Fakultas keguruan dan ilmu pendidikan unsyiah. 1 (2), 63-70.

Gumantan, Aditya dan Mahfud, Imam. (2018). Perbandingan Latihan Dengan Menggunakan Bola Ukuran 4 dan 5 Terhadap Ketepatan Menendang Bola ke Arah Gawang. Journal of S.P.O.R.T. 2 (1), 1 - 7.

Irianto, Djoko Pekik. (2002). Dasar Kepelatihan.Diktat. Yogyakarta: FIK UNY.

Lutan, Rusli. (2002). Asas-Asas Pendidikan Jasmani Pendekatan Pendidikan Gerak Disekolah Dasar. Jakarta: Depdiknas.

Mahfud, Imam. Fahrizqi, Eko Bagus. (2020). Pengembangan Model Latihan Keterampilan Motorik Melalui Olahraga Tradisional. Untuk Siswa Sekolah Dasar. Sport Science and Education Journal. 1 (1), 31-37.

Mahfud, Imam. Gumantan, Aditya. Fahrizqi, Eko Bagus. (2020). Analisis IMT (Indeks Massa Tubuh) Atlet UKM Sepakbola Universitas Teknokrat Indonesia. SATRIA Journal Of "Sports Athleticism in Teaching and Recreation on Interdisciplinary Analysis". 3 (1), 9-13.

Nugroho, Reza Adhi dan Gumantan, Aditya. (2020). Pengaruh Latihan Plyometric Terhadap Peningkatan Kemampuan Vertical Jump Peserta Ekstrakurikuler Bola Basket SMAN 1 Pagelaran. Sport Science and Education Journal. 1 (1), 31-37.

Sajoto, Muhammad. (1995). Pembinaan Kondisi Fisik Olahraga. Jakarta: Depdikbud Dirjen.

Sugiyono. (2010). Metode Penelitian Pendidikan Pendekatan Kualitatif, Kuantitatif, dan R\&D. Bandung: Alfabeta. 


\section{BIOGRAFI PENULIS}

Cahyo Pratomo
lahir di Bukit kemuning, saat ini penulis sedang menempuh Pendidikan Strata 1
di Universitas Teknokrat Indonesia dengan mengambil Program Studi
Pendidikan Olahraga angkatan 2017. Selain Aktif dalam kegiatan Himpunan
Mahasiswa Pendidikan Olahraga, merupakan Ketua Badan Eksekutif
Mahasiswa pada Fakultas Sastra dan Ilmu Pendidikan dan menjadi Assisten
Dosen.
cahyo.pratomo987@gmalis dapat dihubungi melalui Email

